\title{
Teacher Induction Program: First Experience in Turkey
}

\author{
Fatma ÇOBANOĞLU ${ }^{1} \&$ Zeynep Ayvaz-Tuncel ${ }^{1}$ \\ ${ }^{1}$ Department of Educational Administration, Pamukkale University, Turkey \\ Correspondence: Fatma ÇOBANOĞLU, Department of Educational Administration, Pamukkale University, \\ Turkey. E-mail: fcobanoglu@pau.edu.tr
}

Received: January 11, 2018

doi:10.5539/ies.v11n6p99
Accepted: February 15, $2018 \quad$ Online Published: May 29, 2018

URL: https://doi.org/10.5539/ies.v11n6p99

\begin{abstract}
Perspectives on beginning teachers' possible problems and their reasons force many of the countries to develop teacher induction programs. Teacher induction programs are extensive, consistent and ongoing professional processes aiming to train, support, and protect novice teachers. In Turkey, the process of "teacher induction program" which has been initiated in 2016 is a regulation to train novice teachers for six months. The rationale of the program for the novice teachers is to have more practical experience and in turn to teach effectively in their classrooms. As each new regulation can be accompanied by some obscurities, scientific research will serve to increase the quality of the processes and practices in teacher induction programs. In this sense, the current research aims to determine the views of 357 novice teachers on the goal achievement of the teacher induction program. A questionnaire form was developed to collect the data consisting of 43 questions one of which is an open-ended question. Results suggested that preservice education and teacher induction program have similar contributions in regard to the goal achievement of the teacher induction program. Moreover, considering the process as a whole, the mentor has an important role in the development of novice teachers.
\end{abstract}

Keywords: induction program, novice teacher, teacher education, mentors

\section{Introduction}

The quality of a teacher plays an important role in the quality of education, therefore teacher training is a significant matter of issue. Teacher training is divided into three phases as pre-service, induction, and in-service education. Pre-service education is the practices and training activities before starting the teaching profession. As for the induction program, it is the training of adaptation to the conditions faced in the first few years of the teaching profession. In-service education is the training program which aims to strengthen and provide the professional development in all stages of teaching.

The success in the development of a teacher, while experiencing all those phases of education, relies on the support he gets. In spite of the great emphasis on the quality of the teacher training programs and in-service teachers' professional development, little attention is given for the teacher induction programs which will assist the novice teachers' adaptation in their first years of teaching.

The first year of teaching brings many struggles for the novice teacher who has to create a productive learning environment, plan the instruction, assess the students' learning, discover the individual and cultural differences in his working place, and learn about the school, school district as well as the government policies (Youngs, 2007). These responsibilities lead novice teachers to face some problems in the first year of their teaching. A body of literature on teaching (Andrew, Gilbert, \& Martin, 2014; Brock \& Grady, 1998; Helms-Lorenz et al., 2016; Ingersoll \& Smith, 2003; Veenman, 1984) outlines the various reasons for leaving the teaching profession such as seeking for a better career, lack of support, job dissatisfaction, lack of enough ability for effective teaching strategies, or overwhelming teaching assignments.

The main rationale of focusing on the induction programs for the governments is that, as seen in many of the OECD countries, one-third of the teachers leave their job between the third and fifth year of their profession (OECD, 2014). It is a matter of fact that beginning teachers need an effective support. As the reasons for beginning teachers' possible anxiety and burnout are being realized, many of the countries (e.g. France, Greece, Israel, Italy, Japan, New Zealand etc.) have started to develop teacher induction programs. Induction programs are more or less planned and organized regulations which support and help beginning teachers to be sufficient and effective experts (Helms-Lorenz et al., 2016). As for Wong's (2004) definition, induction programs as extensive, consistent and 
ongoing professional processes which aim to train, support and protect novice teachers, and this process represents the first part of a lifelong professional development program.

\subsection{Teacher Induction Program}

As ETUCE (2008) states: "the induction phase, of at least one year's duration, must involve systematic guidance and support for newly qualified teachers and must be both a right and an obligation for the newly qualified teacher". Teacher induction programs are based on the view that novice teachers need individual, social and professional support. The individual support provided by a mentor or a peer who share the workload in the working place in which the novice teacher feels him/herself safe, serves the aim of developing the teacher identity, strengthening the efficiency, increasing the self-confidence, decreasing stress and anxiety, and motivating and avoiding the dropout. Similarly, the social support provided by a mentor serves the aims of socializing at school and in the profession, encouraging the cooperation and cooperative learning, and encouraging joining in a school society. The professional support, which is provided by field experts and colleagues from other schools, has the aims as "developing the teaching efficiency, connecting the professional development and the novice teacher, and providing the novice teachers' professional development" (European Commission Staff Working Document SEC, 2010, p. 16-19).

Ingersoll and Strong (2011) critically examined 15 studies which were conducted on the effects of induction and mentoring programs for the novice teachers, and pointed out similar outcomes for each research despite the distinctive limitations: (a) all the examined research found a positive effect of induction and mentoring programs on novice teachers; (b) nearly in all studies, teachers who participate in such induction programs have more level of professional satisfaction, commitment, and retention; (c) in terms of classroom activities of the novice teachers, many of the research found that teachers participating in such training have a better performance in engaging students to instruction, developing lesson plans, developing effective question and answer practices, preparing activities to meet the students' needs and creating a positive classroom climate; (d) in terms of student achievement, students of teachers who participate in such programs have higher academic test scores.

\subsection{Teacher Induction Program in Turkey}

Introducing the "Teacher Induction program" in 2016 first, The Ministry of National Education (MoNE) aims to fill an important gap in teacher training process. With this regulation, the novice teachers take induction training in the first six months of their first year of teaching. In this sense, beginning teachers undergo training under the responsibility of a mentor and an administrator of the school in a city which they choose. This training includes classroom, in-school and out-school activities, and in-service education. Classroom activities are the practices of monitoring the courses, course planning, preliminary activities, and assessment and classroom activities for 16 weeks. Also, it is the process of monitoring and taking responsibilities in the in-school activities once in a week. The out-school practices are introducing the city identity, visiting different kinds of schools, visiting the bureaucratic institutions and participation in cultural and art activities for 15 weeks. Moreover, the teachers fill a form about the books they have read and the movies they have watched from the list they are assigned. In addition to this training, beginning teachers attend an in-service education for 8 weeks which is given by the ministry, academicians, members of nongovernmental organizations and field experts to increase the professional and personal development of the novice teachers.

The rationale of this regulation which was put into practice for 30 thousand of teachers appointed in February 2016 is that novice teachers can have extra practical experiences and in turn teach professionally in their classes. Inherently, all new regulations bring some obscurities with it. Scientific research will serve to increase the quality of the processes and practices of teacher induction programs. In this sense, a necessity might arouse to determine the participants' views on whether the process of teacher induction program has achieved its goals.

\section{Method}

Surveys can be used to determine the views of individuals about policy issues. Surveys also provide useful information to evaluate programs (Creswell, 2005, p. 354). Thus, in the current research, the survey method was used to examine the views of the participants on the goal achievement of teacher induction program which was first implemented in 2016 in Turkey. As the participants were all included in the induction program together, the data collection tool of the study was implemented in one setting so the researchers had the opportunity to gather the data quickly.

\subsection{Sample and Data Collection}

Participants of the study consist of 494 novice teachers who participated in teacher induction program in Denizli in the 2015-2016 academic year. No sample was chosen for the study, instead, 357 (72\%) voluntary beginning 
teachers who responded the questionnaire and $332(67 \%)$ voluntary beginning teachers who answered the open-ended question were included in the study. Of the participants, $69 \%$ were women $(\mathrm{N}=246), 31 \%$ were men $(\mathrm{N}=111)$. Participants are comprised of 54 classroom teachers $(15 \%), 297$ field teachers $(83 \%)$ and 43 school counselors $(2 \%)$. Participants were graduated from either the faculty of education $(69 \%, N=248)$ or other faculties $(31 \%-, N=09)$.

Data was collected via a two-part questionnaire developed by the researchers. While developing the form, the legal instruction of teacher induction program (MoNE, 2015) was examined and 10 learning outcomes about the classroom, in-school, and out-school activities were written down as 13 questionnaire items. Three separate questionnaire forms were prepared in order to determine the contributions of pre-service education, teacher induction program, and the appointed mentors to each of the outcomes as a whole (Table 1).

Table 1. Sample of questionnaire items

\begin{tabular}{llll}
\hline Related to planning instruction & & \\
\hline The pre-service education I was graduated (faculty of education, pedagogical formation program) was sufficient. & 3 & 2 & 1 \\
The teacher induction program I participated was sufficient with regard to my personal and professional development. & 3 & 2 & 1 \\
Mentor contributed to me related to my personal and professional development. & 3 & 1 \\
\hline
\end{tabular}

Additionally, three more items were added to the form in order to determine the contribution of the assigned books, movies and the city preference of the novice teachers about where they wish to participate in the program. The questionnaire was a Three-Point Likert type form which the participants would respond to the items as (1) insufficient, (2) partially sufficient, or (3) sufficient. To get the unplanned or unexpected responses and in turn to have a more comprehensive and elaborated data about the issue (Büyüköztürk, 2005), an open-ended question was also added to the questionnaire form. Prepared as a commentary question, the participants were expected to make a general evaluation of the process via the question so that the researchers would obtain more fairly and elaborated responses. Field experts were evaluated the form and then a pilot study was conducted to organize its final form.

\subsection{Data Analysis}

The values of skewness and kurtosis were -1.51 and -1.54 respectively. Also, the descriptive statistics scores (mean, median and mode) fell close on the curve. As a result, the distribution was observed to be normal. On the basis of the mean scores obtained from the questionnaire items, "1.00-2.33" indicates the views as insufficient, "2.34-3.67" as partially sufficient and "3.68-5.00" as sufficient. The data were grouped considering the relationships among the items, and each response of the novice teachers was presented by comparing the pre-service education, the process of teacher induction program and the contribution of the appointed mentor.

A data set was constructed by arranging the data collected via the open-ended question at first, and then the content analysis was made. Through the codes, the themes were determined and the relation between a code and the theme on the data set was examined in terms of external heterogeneity and internal homogeneity.

\section{Results}

Novice teachers' views on the contribution of pre-service education, induction program and their mentors in terms of "planning, performing, and assessment of a lesson; preparing and using materials and defining and solving possible problems in educational process" are shown in Table 2. 
Table 2. Views of the novice teachers on contribution of the processes (1)

\begin{tabular}{|c|c|c|c|c|c|c|c|c|c|}
\hline & \multicolumn{3}{|c|}{$\begin{array}{c}\text { Sufficiency of pre-service } \\
\text { education }\end{array}$} & \multicolumn{3}{|c|}{$\begin{array}{l}\text { The contribution of teacher } \\
\text { induction program }\end{array}$} & \multicolumn{3}{|c|}{ The contribution of mentor } \\
\hline & $\mathrm{X}$ & $\mathrm{SD}$ & Level & $\mathrm{X}$ & SD & Level & $\mathrm{X}$ & SD & Level \\
\hline Planning & 2.50 & .68 & Sufficient & 2.15 & .75 & $\begin{array}{l}\text { Partially } \\
\text { Sufficient }\end{array}$ & 2.38 & .75 & Sufficient \\
\hline Performing & 2.47 & .70 & Sufficient & 2.26 & .73 & $\begin{array}{l}\text { Partially } \\
\text { Sufficient }\end{array}$ & 2.42 & .73 & Sufficient \\
\hline Assessment & 2.46 & .72 & Sufficient & 2.20 & .78 & $\begin{array}{c}\text { Partially } \\
\text { Sufficient }\end{array}$ & 2.34 & .79 & Sufficient \\
\hline $\begin{array}{l}\text { Preparing and using } \\
\text { materials. }\end{array}$ & 2.49 & .70 & Sufficient & 2.10 & .79 & $\begin{array}{l}\text { Partially } \\
\text { Sufficient }\end{array}$ & 2.25 & .81 & $\begin{array}{l}\text { Partially } \\
\text { Sufficient }\end{array}$ \\
\hline $\begin{array}{l}\text { Defining and solving } \\
\text { possible problems at } \\
\text { educational process. }\end{array}$ & 2.33 & .75 & $\begin{array}{l}\text { Partially } \\
\text { Sufficient }\end{array}$ & 2.27 & .78 & $\begin{array}{l}\text { Partially } \\
\text { Sufficient }\end{array}$ & 2.35 & .77 & Sufficient \\
\hline
\end{tabular}

As seen in Table 2, novice teachers found the contribution of the pre-service education and their mentors in terms of planning, teaching and assessing a course more sufficient than of the induction program. Moreover, novice teachers think that pre-service education's contribution is sufficient in terms of preparing materials, and mentor's contribution is sufficient in terms of identifying a problem and finding a solution in teaching and learning process.

Novice teachers' views on the contribution of pre-service education, induction program and their mentors in terms of "doing educational activities in schools; recognizing the educational environment and social structure of the school they will work; getting to know the stakeholders and their responsibilities; being aware of the social responsibility initiatives and volunteering; being capable of preparing monitoring and assessment reports about educational processes and out of school activities" are shown in Table 3.

Table 3. Views of the novice teachers on the contribution of the processes (2)

\begin{tabular}{|c|c|c|c|c|c|c|c|c|c|}
\hline & \multicolumn{3}{|c|}{$\begin{array}{c}\text { Sufficiency of the pre-service } \\
\text { education }\end{array}$} & \multicolumn{3}{|c|}{$\begin{array}{l}\text { Contribution of the teacher } \\
\text { induction program }\end{array}$} & \multicolumn{3}{|c|}{ Contribution of the mentor } \\
\hline & $\mathrm{X}$ & SD & Level & $\mathrm{X}$ & SD & Level & $\mathrm{X}$ & SD & Level \\
\hline $\begin{array}{l}\text { Doing educational activities } \\
\text { (teacher council, meetings, } \\
\text { guidance council meetings, } \\
\text { extra-curricular activities, } \\
\text { supervision and the others) in the } \\
\text { school. }\end{array}$ & 2.10 & .80 & $\begin{array}{l}\text { Partially } \\
\text { Sufficient }\end{array}$ & 2.24 & .76 & $\begin{array}{l}\text { Partially } \\
\text { Sufficient }\end{array}$ & 2.29 & .77 & $\begin{array}{l}\text { Partially } \\
\text { Sufficient }\end{array}$ \\
\hline $\begin{array}{l}\text { Recognizing the educational } \\
\text { environment and social structure } \\
\text { of the school they will work. }\end{array}$ & 2.09 & .84 & $\begin{array}{l}\text { Partially } \\
\text { Sufficient }\end{array}$ & 2.13 & .83 & $\begin{array}{l}\text { Partially } \\
\text { Sufficient }\end{array}$ & 2.18 & .83 & $\begin{array}{c}\text { Partial } \\
\text { Sufficient }\end{array}$ \\
\hline $\begin{array}{l}\text { Getting to know the stakeholders } \\
\text { (the governor, municipality, } \\
\text { director of the national education, } \\
\text { the center for guiding research, } \\
\text { and center of in-service } \\
\text { education) and their } \\
\text { responsibilities }\end{array}$ & $\mathrm{s}$ & .82 & $\begin{array}{l}\text { Partially } \\
\text { Sufficient }\end{array}$ & 2.45 & .73 & Sufficient & 2.25 & .79 & $\begin{array}{l}\text { Partially } \\
\text { Sufficient }\end{array}$ \\
\hline $\begin{array}{l}\text { Being aware of the social } \\
\text { responsibility initiatives and } \\
\text { volunteering }\end{array}$ & 2.46 & .75 & Sufficient & 2.33 & .79 & $\begin{array}{l}\text { Partially } \\
\text { Sufficient }\end{array}$ & 2.22 & .81 & $\begin{array}{l}\text { Partially } \\
\text { Sufficient }\end{array}$ \\
\hline $\begin{array}{l}\text { Being capable of preparing, } \\
\text { monitoring and assessing the } \\
\text { reports about educational } \\
\text { processes and out-school } \\
\text { activities. }\end{array}$ & 2.22 & .82 & $\begin{array}{l}\text { Partially } \\
\text { Sufficient }\end{array}$ & 2.35 & .74 & Sufficient & 2.28 & .79 & $\begin{array}{l}\text { Partially } \\
\text { Sufficient }\end{array}$ \\
\hline
\end{tabular}


Table 3 shows that pre-service education creates enough awareness for the novice teachers on social responsibility and voluntary based projects. Besides, the induction program has a sufficient contribution in terms of getting to know stakeholders, learning the operational processes and preparing a monitoring and evaluation report for the educational processes and the out-school activities. However, novice teachers could not take enough encouragement from the mentors in their training process about the educational activities at school and the environment of the school that they will work in.

Novice teachers' views on the contribution of pre-service education, induction program and their mentors in terms of "Realizing the importance of professional development and sharing educational experiments" and "developing a positive attitude towards the teaching profession or loving the profession" are shown in Table 4.

Table 4. Views of the novice teachers on the contribution of the processes (3)

\begin{tabular}{|c|c|c|c|c|c|c|c|c|c|}
\hline & \multicolumn{3}{|c|}{$\begin{array}{c}\text { Sufficiency of the pre-service } \\
\text { education }\end{array}$} & \multicolumn{3}{|c|}{$\begin{array}{l}\text { Contribution of the teacher } \\
\text { induction program }\end{array}$} & \multicolumn{3}{|c|}{ Contribution of mentor } \\
\hline & $\mathrm{X}$ & $\mathrm{SD}$ & Level & $\mathrm{X}$ & $\mathrm{SD}$ & Level & $\mathrm{X}$ & SD & Level \\
\hline $\begin{array}{l}\text { Realizing the importance of } \\
\text { professional development }\end{array}$ & 2.61 & .65 & Sufficient & 2.45 & .72 & Sufficient & 2.45 & .73 & Sufficient \\
\hline $\begin{array}{l}\text { Realizing the importance of } \\
\text { sharing educational experience }\end{array}$ & 2.42 & .73 & Sufficient & 2.43 & .72 & Sufficient & 2.47 & .73 & Sufficient \\
\hline $\begin{array}{l}\text { Developing a positive attitude } \\
\text { towards the teaching profession } \\
\text { or loving the profession. }\end{array}$ & 2.58 & .69 & Sufficient & 2.19 & .84 & $\begin{array}{l}\text { Partially } \\
\text { Sufficient }\end{array}$ & 2.33 & .82 & $\begin{array}{l}\text { Partially } \\
\text { Sufficient }\end{array}$ \\
\hline
\end{tabular}

Table 4 shows that all the processes had a contribution to the novice teachers in terms of understanding how important are to share the experiences about the professional development and education. Nevertheless, pre-service education has more contribution to developing a positive attitude towards the teaching profession than the other education phases have.

Novice teachers" views on the contributions of "books and movies" throughout the induction program and "the city preference" are given in Table 5.

Table 5. Views of the novice teachers on books and movies assigned, and the city preference for the induction program

\begin{tabular}{|c|c|c|c|}
\hline & $X$ & $\mathrm{SD}$ & Level \\
\hline $\begin{array}{l}\text { The contribution of the books about education and the teaching profession to the professional } \\
\text { development. }\end{array}$ & 2.63 & .65 & Sufficient \\
\hline $\begin{array}{l}\text { The contribution of the movies about education and the teaching profession to professional } \\
\text { development. }\end{array}$ & 2.67 & .66 & Sufficient \\
\hline $\begin{array}{l}\text { The contribution of participating in the program wherever they want regarding the adaptation to the } \\
\text { city they will work. }\end{array}$ & 2.08 & .89 & $\begin{array}{l}\text { Partially } \\
\text { Sufficient }\end{array}$ \\
\hline
\end{tabular}

As displayed in Table 5, books and movies had sufficient contributions throughout the induction program. Nevertheless, participating the program in Denizli din not have much contribution regarding the adaptation to the appointed city.

Examining the general comments of the novice teachers about the process, there are three themes named as "positive comments", "negative comments" and "suggestions for the future practices of the induction program". The codes under the theme of "Positive comments" were given in Table 6. 
Table 6. Positive views of the novice teachers on their evaluation of the process in general

\begin{tabular}{lll}
\hline & Codes & $\mathrm{f}$ \\
\cline { 2 - 3 } Peing experienced in performing. & 53 \\
& Contribution of the mentor & 34 \\
& Positive assessment of the process & 26 \\
& Adapting to the teaching profession & 12 \\
& Positive views on participating in the program wherever they want & 7 \\
& Supporting the pre-service education & 6 \\
& Taking the advantage of experienced teachers & 5 \\
\hline
\end{tabular}

Some of the novice teachers who have positive views about the teacher induction program stated that their experience in practice increased. One of the teachers said "It was productive, especially classroom practices provide experiences for me (T 196)" while the other teacher commented such as "Teacher induction program have a positive contribution to my professional development in general. I had some experiences in teaching a course ( $T$ 218). " Similarly, some of the novice teachers emphasized the support of their mentors and the facilitating role of the process for the adaptation to the teaching profession. Some of the statements of the teachers are as below: "The positive side of the program was that instead of starting the teaching at once, we entered classrooms with mentors and this led to an adaptation and orientation. What's more, it provided a direct observation of the problems and their solutions in the class (T 240)"; "It caused me to understand the teaching profession more deeply. I recognized the classroom and school environments better (T 58)." One of the beginning teachers evaluated the city preference as a positive situation and stated that "We did not change the city in a sudden. We had more time to get more information about the place we would go". The novice teachers also indicated that the process supports the pre-service education and one of them stated that "The teacher induction process was beneficial in general. In college, many issues have been just in theoretical level and teaching practice courses were not enough. During the induction period, I quickly recognized my deficiencies and also I got the advantage of working with more experienced teachers (T 1)".

The novice teachers' negative views on teacher induction program were another theme of the research. The codes under the theme of "Negative comments" were given in Table 7.

Table 7. Negative views of the novice teachers on their evaluation of the process in general

\begin{tabular}{|c|c|c|}
\hline \multirow{13}{*}{ Negative views } & Codes & $\mathrm{f}$ \\
\hline & Negative views on in-service education (its trainers, programs, length of time) & 75 \\
\hline & Negative views on the forms assigned & 70 \\
\hline & The problems due to a new implementation. & 68 \\
\hline & Negative evaluation of the process. & 62 \\
\hline & Problems due to the mentors. & 52 \\
\hline & Role conflict & 21 \\
\hline & Willing to be a teacher immediately & 20 \\
\hline & Negative views on the management of the process. & 20 \\
\hline & Improper school for the implementation of the process & 16 \\
\hline & Repetition of the pre-service education. & 10 \\
\hline & Develop a negative attitude towards the profession & 7 \\
\hline & Negative views on experienced teachers in the process. & 5 \\
\hline
\end{tabular}

Examining this theme, novice teachers expressed negative views more on seminars than on the other issues (the long periods for seminars, the trainers, and the program content). Some quotations from the teachers reflect those views: "Teacher induction program is necessary however it should not have been such long. All the information we had learned at school for 3 and a half month were presented again under the name of summer seminars. I think it was an extra waste of time (T 56)", and "Teacher induction program was a difficult period for me. Summer seminars which were given in addition to the weekly seminars were not useful. We have repeated the same content (T 219)". The forms required from the novice teachers in the program seem to affect their views negatively also. Teachers commented on this issue such that; "All were theoretical and the workload (the forms) was too much ( $T$ 180)"; "To write too many reports throughout the process made me feel tired (T 206)"; "The most negative side of the induction program was to make us prepare reports and daily plan as an unnecessary waste of paperwork ( $T$ 
44)"; "We became a master of writing down not being a teacher because of the forms that we had to fill in. These forms and continuously changing rules about them led us not to concentrate on teaching (T 123); and "I don't remember anything except the forms (T 204)."

The novice teachers stated that they had problems due to the program being the first and commented as "There were some failing points because the program was processed for the first time (T 12)", and "obscurities of the first program forced the teachers too much (T 104)." Teacher also evaluated the process negatively because of their mentors: "I have not learned any new method or technique from my mentor, instead s/he has learned from me (T 180), "As a beginning teacher I definitely think that I have not taken the advantage of my mentor in the period...S/he blunted my enthusiasm for the teaching profession. As s/he was always in a polemic with the students in the class, I don't think that s/he was a good role model for me (T 16). ” Another factor for the negative comments of the teachers is the role conflicts they experienced: "We have been treated like students (T 79); "We have not been treated as appointed teachers but as pre-service teachers (T 213)"; and "We have not completely felt as teachers. Moreover, in seminars, we have continuously treated as students and this caused a lack of confidence (T 234)".

Another negative view of the novice teachers about the process is that they participated in the program in inappropriate schools. As one teacher said: "Novice teachers should make their induction which matches their appointed school type. I will be working in a technical school but the Board of National Education in Denizli had arranged my induction program in a secondary school (T 51)". Also, T92 stated that "As a teacher who was appointed to a primary school, I would have preferred not to make my internship in a high school." Furthermore, the novice teachers who are willing to start teaching soon also commented negatively about the process: "I want to meet my students as soon as possible; before I lose my interest (T 30)"; "I immediately want to meet my school and students (T 149)"; "I want to meet my students. It makes me feel tired to be provisional; I lost my interest (T 154)'. Unfortunately, the views of the beginning teachers indicate that the induction program also developed some negative attitudes towards the teaching profession: "This process passed away the teachers' excitement (T 151)"; "I think this process has led to an alienation for teaching (T 213)" and "When I evaluate the process in general, I see that it did not help me and killed my enthusiasm and interest at the beginning (T 180)".

The novice teachers also made some suggestions about the induction process. The codes under the theme of suggestion about the process were given in Table 8 .

Table 8. Views of the novice teachers on their evaluation of the process in general

\begin{tabular}{lll}
\hline \multirow{4}{*}{ Suggestions } & Codes & $\mathrm{f}$ \\
\cline { 2 - 3 } & Enhancing the teacher performance in practicing. & 41 \\
& Mentor selection & 26 \\
& Preparing the forms in a digital environment & 7 \\
& Organizing the program based on branches. & 7 \\
& Integrating the process with the pre-service education. & 4 \\
\hline
\end{tabular}

Besides positive or negative views, novice teachers also made some suggestions for enhancing the process. For this issue, the teachers especially suggested more practice throughout the process: "Teachers should be in the field (class) more (T 42)"'The practice period should be longer (T 72)"; "We could have been more active in classrooms instead of filling the forms and listening to the same issues at seminars again and again (T 201)"; "I would be more effective if they emphasized the practices more (T 105)". Apart from this, teachers also made some suggestions about the mentor selection: "...I wish the mentors were chosen voluntarily. My mentor did not want to do this work and also me (T 242)"; "...To make the process more productive, more importance should be given to the mentor selection (T 313)”; “...they (the mentors) should be chosen from the volunteers (T 344)”; “...they should be selected by an interview and only the volunteers should do this job not the ones who give all his/her workload to you (T 31); “..the mentor should be selected more carefully. The mentor should be open-minded, know the methods and techniques and love his/her job (T 145)." In addition to all these suggestions, some beginning teachers suggested that field-specified programs should be conducted, and this process should be integrated with the preservice education.

\section{Discussion}

Qualities of a teacher have an important effect on students' achievement. Consequently, the teacher training process should be carefully organized and handled in a multidimensional way. Pre-service education for 
developing the teacher quality throughout the college education, teacher induction program as an introduction to the teaching profession and in-service education for professional development should be evaluated and arranged in an integrated way. The purpose of the current study, which focused on the pre-service education and the induction program, was to determine the contribution of those processes to the novice teachers in terms of some qualifications.

During the college education, pre-service teachers try to gain much of the information, skills, and attitudes about the teaching profession. These abilities for teaching profession are also identified as the required outcomes of the teacher induction program. There are similar outcomes, both in pre-service education and in induction program in terms of planning, conducting and assessing a course, preparing materials and coping with undesirable behaviors. These outcomes all serve to make the limited time at school more effective and productive. The current study found that the pre-service education makes enough contribution to the pre-service teachers in terms of managing the instruction. The views of the participants that the teacher induction program is the repetition of the pre-service education support this conclusion. Moreover, in terms of the social responsibility and constructing an awareness of voluntariness, pre-service education is also regarded to have enough contribution. Practices in the course of social services in teacher training programs have an important role to construct this awareness.

The results of this study showed that pre-service education has a more effect on novice teachers' gaining positive attitudes towards teaching profession than the induction program have. However, although they start the teacher induction program with this positive attitude, some of the novice teachers' attitudes were affected negatively by the process. A possible explanation for this is some of the experienced teachers' negative perspectives and burn out. The situation that the teacher induction program is insufficient to develop positive attitudes towards the teaching profession should be questioned in terms of the effectiveness of outcomes. Regarding the qualitative data, being long, not having an independent class and role conflicts are some of the issues which were effective for developing negative attitudes. The mentors referred to the novice teachers either as a student, pre-service teachers, intern or a teacher, and this might lead to a role conflict for the novice teachers. Kılıç, Babayiğit, and Erkuş (2016) emphasized in their study that considering the novice teachers as students might be a disadvantage of the process.

Results revealed that the teacher induction program was sufficient in the outcomes related to the identity information of the stakeholders that are expected to contribute to the students' education, and to the operation of the process, furthermore, to monitor various situations and prepare an evaluation form. Öztürk (2016) found in his research that before this program, the novice teachers had difficulty in preparing legal documents, reports, and official correspondence. Then it might be an effective effort in the sense that more theoretical information on administrative processes takes place in pre-service education. Furthermore, novice teachers might remove their lack of practical experience throughout the teacher induction program. On the other hand, to organize the forms and reports according to the current situations might definitely make the process more efficient. Ulubey (2016) also reported that it is required to decrease the forms or removing them during the program. Likewise, in a study by SETA (2016), beginning teachers commented negatively on reports. According to the European Commission Staff Working Document (2010), for the novice teachers, all their lessons are new and need a careful preparation. Together with a lack of experience, this can create a very heavy workload.

The mentor which is selected for each of the novice teachers in the scope of this program has a significant role in reaching the outcomes. What's more, the mentor is important in terms of gaining the practical experience which supports the pre-service education to reach the outcomes of planning, conducting, and assessment of a course. Yapıcioğlu et al. (2016) found that this process also contributes to the issues of classroom management, technology usage, and effective time management.

It is significant that the program contributed to the novice teachers in terms of identifying the problems in teaching and learning process, and finding solutions for them. This is important to remove the practical deficit of courses such as classroom management. However, considering the qualitative data, although the mentor has a significant role in reaching the outcomes and gaining the practical experience, his attitude and inappropriate mentor selection might affect the process negatively. Balkar and Şahin (2015) concluded in their study that it is not necessary for a teacher to have more experience to be a mentor; being successful and willing to help is enough. Nevertheless, in the report of ETUCE (2008), the mentors are identified as completely qualified and experienced. Mentors are expected to perform professional characteristics and to have sufficient current knowledge and skills. Wong (2004) also indicated that mentors should get involved in the induction program consistent with the district's vision, mission, and structure. Nevertheless Soyalp and Kozikoğlu (2016) stated that mentors do not have enough information about the process, and similarly, Kozikoğlu and Senemoğlu (2016) stated that negative relationship between the mentor and the novice teacher cause problems. 
Results also suggested that the program was successful in terms of all the environments of interaction included and all the processes based on comprehending the importance of professional development and sharing experiences have reached its outcomes. Assigned movies and books also contributed to the professional development of the novice teachers. In the report of SETA (2016), movies have more contribution to the professional and individual development of the teachers than the books have.

There seem to be some problems with the teacher induction program which was implemented in 2016 because of its being the first. Significantly, teachers did not experience this process in their appointed city so this leads not to know much about the educational and social environment. What's more, the most negative part of the process emphasized by the teachers is that after the 16 weeks of classroom, in-school, and out-school activities, they had extra 8 weeks of in-service education. Sarıca and Özpolat (2016) also outlined that the novice teachers have negative views because of the reasons such as much work-load, not having a summer holiday and some troubles during the process and etc.

Taken together, results suggested that the teacher induction program supported the teacher training process from different perspectives, contributed to the novice teachers in terms of teaching practices, gaining awareness for the management process, and might be more effective with some arrangements. Soyalp and Kozikoğlu (2016) concluded that observations for classroom practices and teaching a class are important for the professional development. Also, Ulubey (2016) stated that novice teachers find the program positive, and the program prepares the novice teachers for the profession as in its outcomes. Nevertheless, Oral and Demir (2016) indicated that along with the program's being a guide for a teacher, this process is not necessary, additionally, the tasks and works are quantitative rather than qualitative.

The strength of the induction program might be getting know the stakeholders of education and being aware of the importance of it regarding the deficits of the pre-service education. Furthermore, monitoring and evaluating the out-school activities, benefiting from the media tools which support the professional development might also be evaluated as the advantages of the program.

The current study has a number of important implications for future practices. Firstly, the mentors have a significant role in reaching the goals of induction program and contributing to the professional development of novice teachers with their experiences. Therefore, it might be suggested that mentor selection should be made carefully considering the professional quality and voluntariness. Moreover, forms filled throughout the process might be evaluated qualitatively and quantitatively, and unnecessary workload might be decreased. In this sense, the period in the classroom and practical experiences might be increased regarding the professional development.

Secondly, it is also suggested to compare the results of the research on induction program in other countries with the results in Turkey. What's more, required arrangements might be made by analyzing the research results in terms of planning, implementing and evaluating the process.

Finally, in order to determine the contribution of this process to the novice teachers, the comparative studies might be conducted with the participants and non-participants of this process. In this way, the value of the practice for increasing the teacher quality might be determined.

Along with the implications, the current study might be evaluated with its limitations which are that a single data collection tool was used, and the study was conducted in one city. However, the consistency with the results of other research on induction program might decrease the effects of these limitations.

\section{Acknowledgments}

This research was presented at $26^{\text {th }}$ International Congress on Educational Sciences (ICES/UEBK-2017) which was held on 18-22 April 2017 in Antalya, Turkey.

\section{References}

Andrews S. P., Gilbert L. S., \& Martin E. P. (2014). First Years of Teaching The First Years Of Teaching: Disparities In Perceptions Of Support. BASE, EBSCOhost (accessed January 10, 2018).

Balkar, B., \& Şahin, S. (2015). “Teacher induction programme as a new teacher training approach.” Mersin University Journal of Faculty of Education, 11(1).

Brock, B. L., \& Grady, M. L. (1998). Beginning teacher induction programs: the role of the principal. The Clearing House, 3,179. https://doi.org/10.1080/00098659809599355

Büyüköztürk, Ş. (2005). Anket geliştirme. Türk Eğitim Bilimleri Dergisi, 3(2), 133-151.

Creswell, J. W. (2005). Educational research. New Jersey: Pearson Education Insurance. 
ETUCE. (2008). Teacher Education in Europe. An ETUCE Policy Paper. Retrieved from https://www.csee-etuce.org/images/attachments/ETUCE_PolicyPaper_en.pdf

European Commission Staff Working Document. (2010). Developing coherent and system-wide induction programmes for beginning teachers: A handbook for policymakers, SEC (2010) 538 final. Retrieved from http://ec.europa.eu/dgs/education_culture/repository/education/policy/school/doc/handbook0410_en.pdf

Helms-Lorenz, M., Grift, W., \& Maulana, R. (2016). Longitudinal effects of induction on teaching skills and attrition rates of beginning teachers. School Effectiveness and School Improvement, 27(2), 178-204. https://doi.org/10.1080/09243453.2015.1035731

Ingersoll, R. M., \& Smith, T. M. (2003). The wrong solution to the teacher shortage. Educational Leadership, 8 , 30.

Ingersoll, R., \& Strong, M. (2011). The Impact of Induction and Mentoring Programs for Beginning Teachers: A Critical Review of the Research. Review of Education Research, 81(2), 201-233. https://doi.org/10.3102/0034654311403323

Kılıç, D., Babayiğit, Ö., \& Erkuş, B. (2016). Aday öğretmenlerin adaylık eğitimine ilişkin görüşleri. EKEV Akademi Dergisi, 20(68), 81-91.

Kozikoğlu, İ., \& Senemoğlu, N. (2016). Challenges faced by novice teachers: A qualitative study. 4th International Conference on Curriculum and Instruction Abstract Book (p. 107).

Kürüm-Yapıcığlu, D., Öztürk, T., \& Yetim, N. (2016). Are you a pre-service teacher, a mentee or a teacher?: A study on the mentoring practice. 4th International Conference on Curriculum and Instruction Abstract Book (p. 441).

MoNE (Ministry of National Education). (2015). Regulation an Appointment and Relocation of 2015.

OECD. (2014). Education at a glance 2014: OECD Indicators. OECD Publishing. https://doi.org/10.1787/eag-2014-en

Oral, Ş., \& Demir, F. (2016). The opinion of teacher candidates related to the process of educating teacher candidates. 4th International Conference on Curriculum and Instruction Abstract Book (p. 694).

Öztürk, M. (2016). Köy ve kasabalarda görev yapan öğretmenlerin mesleğin ilk yılında yaşadıkları güçlükler. Elementary Education Online, 15(2), 378-390.

Sarıca, R., \& Turan-Özpolat, E. (2016). Teacher candidates' opinions about the teacher candidate training process. 4th International Conference on Curriculum and Instruction Abstract Book (p. 626).

SETA. (2016). Türkiye'de aday öğretmen yetiştirme modeli izleme ve değerlendirme raporu. SETA Yayınları, İstanbul.

Soyalp, H., \& Kozikoğlu, İ. (2016). Investigation of novice teachers' opinions concerning induction program. 4th International Conference on Curriculum and Instruction Abstract Book (p. 503).

Ulubey, Ö. (2016). Evaluation of the Pre-service Teacher Training Program in light of the Opinions of Pre-service Teachers. 4th International Conference on Curriculum and Instruction Abstract Book (p. 482).

Veenman, S. (1984). Perceived Problems of Beginning Teachers. Review Of Educational Research, 2, 143. https://doi.org/10.3102/00346543054002143

Wong, H. K. (2004). Induction programs that keep new teachers teaching and improving. NASSP Bulletin, 88(638), 41-58. https://doi.org/10.1177/019263650408863804

Youngs, P. (2007). How elementary principals' beliefs and actions influence new teachers' experiences. Educational Administration Quarterly, 43(1), 101-137. https://doi.org/10.1177/0013161X06293629

\section{Copyrights}

Copyright for this article is retained by the author(s), with first publication rights granted to the journal.

This is an open-access article distributed under the terms and conditions of the Creative Commons Attribution license (http://creativecommons.org/licenses/by/4.0/). 